\title{
Key to larvae of the South American subfamilies of weevils (Coleoptera, Curculionoidea)
}

\author{
Clave para larvas de las subfamilias sudamericanas de gorgojos (Coleoptera, Curculionoidea)
}

\author{
ADRIANA E. MARVALDI ${ }^{1}$
}

${ }^{1}$ Instituto Argentino de Investigaciones de las Zonas Áridas (IADIZA),
Casilla de Correos 507, 5500 Mendoza; e-mail: marvaldi@lab.cricyt.edu.ar

\begin{abstract}
The weevils (Coleoptera: Curculionoidea) from South America are classsified into seven families and 28 subfamilies as follows: Nemonychidae (Rhinorhynchinae), Anthribidae (Anthribinae), Belidae (Belinae and Oxycoryninae), Attelabidae (Attelabinae and Rhynchitinae), Brentidae (Apioninae and Brentinae), Caridae (Carinae) and Curculionidae (Erirhininae, Dryophthorinae, Entiminae, Aterpinae, Gonipterinae, Rhythirrininae, Thecesterninae, Eugnominae, Hyperinae, Curculioninae, Cryptorhynchinae, Mesoptiliinae (= Magdalidinae), Molytinae, Baridinae, Lixinae, Conoderinae (= Zygopinae), Cossoninae, Scolytinae and Platypodinae). A dichotomous key for the larval stage is provided for identification of the families and subfamilies of Curculionoidea present in South America. The key is based on external morphological characters and contains data on larval feeding habits.
\end{abstract}

Key words: Curculionoidea, South America, identification, larvae.

\section{RESUMEN}

Los gorgojos (Coleoptera: Curculionoidea) de Sudamérica están clasificados en siete familias y 28 subfamilias como se muestra a continuación: Nemonychidae (Rhinorhynchinae), Anthribidae (Anthribinae), Belidae (Belinae y Oxycoryninae), Attelabidae (Attelabinae y Rhynchitinae), Brentidae (Apioninae y Brentinae), Caridae (Carinae) y Curculionidae (Erirhininae, Dryophthorinae, Entiminae, Aterpinae, Gonipterinae, Rhythirrininae, Thecesterninae, Eugnominae, Hyperinae, Curculioninae, Cryptorhynchinae, Mesoptiliinae (= Magdalidinae), Molytinae, Baridinae, Lixinae, Conoderinae (= Zygopinae), Cossoninae, Scolytinae y Platypodinae). Se brinda una clave dicotómica para el estado de larva de Curculionoidea en Sudamérica, para su determinación a nivel de familias y subfamilias. La clave está basada sobre caracteres morfológicos externos y se presentan además datos de hábitos alimentarios.

Palabras clave: Curculionoidea, Sudamérica, identificación, larvas.

\section{INTRODUCTION}

The weevils are characteristic beetles of the Superfamily Curculionoidea, mostly phythophagous as both adults and larvae. They comprise about 60,000 species worldwide, grouped in 6,000 genera (Thompson 1992). In South America there are approximately 10,000 species described, in about 1,000 genera (Wibmer \& O'Brien 1986, Alonso-Zarazaga \& Lyal 1999). However, a very small proportion of genera and species are described at the larval stage. The knowledge on immature weevils is particularly scarce in South America, smallness compared with the high taxonomic diversity present in the area. Although this makes it not possible to identify the larvae of South American weevils to genus, representatives of the different families and subfamilies have now been described (e.g., Rosado-Neto 1980, Costa et al. 1988, May 1993, Marvaldi 1998a-c, Marvaldi \& Morrone 1998, Lanteri et al. 2002). Identification of weevil larvae is important and necessary in systematic studies as well as in many other fields (Burke \& Anderson 1976); it can contribute to studies in ecology, soilsciences, and applied entomology (such as pest management and biological control). The present key, to larvae of Curculionoidea present in South America, is aimed to identify representatives of this development stage at higher taxonomic level (family and subfamily). 


\section{Larvae of the Order Coleoptera}

Beetle larvae are very diverse in morphology (see Lawrence 1991) but the following combination of features may distinguish them from those of other insect orders: Head capsule well-developed and sclerotized, with an ecdysial line (usually Y-shaped) that divides the cranium into a frons and two epicranial areas; antennae with four to one segments and a sensorium; stemmata (larval ocelli) in number of six or fewer on each side; mouthparts of the chewing type, with opposable mandibles, without labial silk glands; thoracic legs with six to fewer segments, sometimes vestigial or completely absent; abdominal prolegs almost always absent; abdomen with 10 segments, with segment IX variously modified (sometimes bearing paired dorsal processes or urogonphi), segment $\mathrm{X}$ reduced and without cerci; respiratory system usually with nine pairs of spiracles, placed on thorax (often on mesothorax) and on abdominal segments I-VIII.

\section{Larvae of the Superfamily Curculionoidea}

Most weevil larvae live inside dense substrates, like plant tissues, fungi, or soil, with few instances of aerial external feeding (Marvaldi et al. 2002). A morphological characterization of the Curculionoid larvae is as follows (Fig. 1 and 2): comma-shaped grubs; with soft (usually whitish) abdominal segments, the first seven or eight transversely divided into two to four dorsal
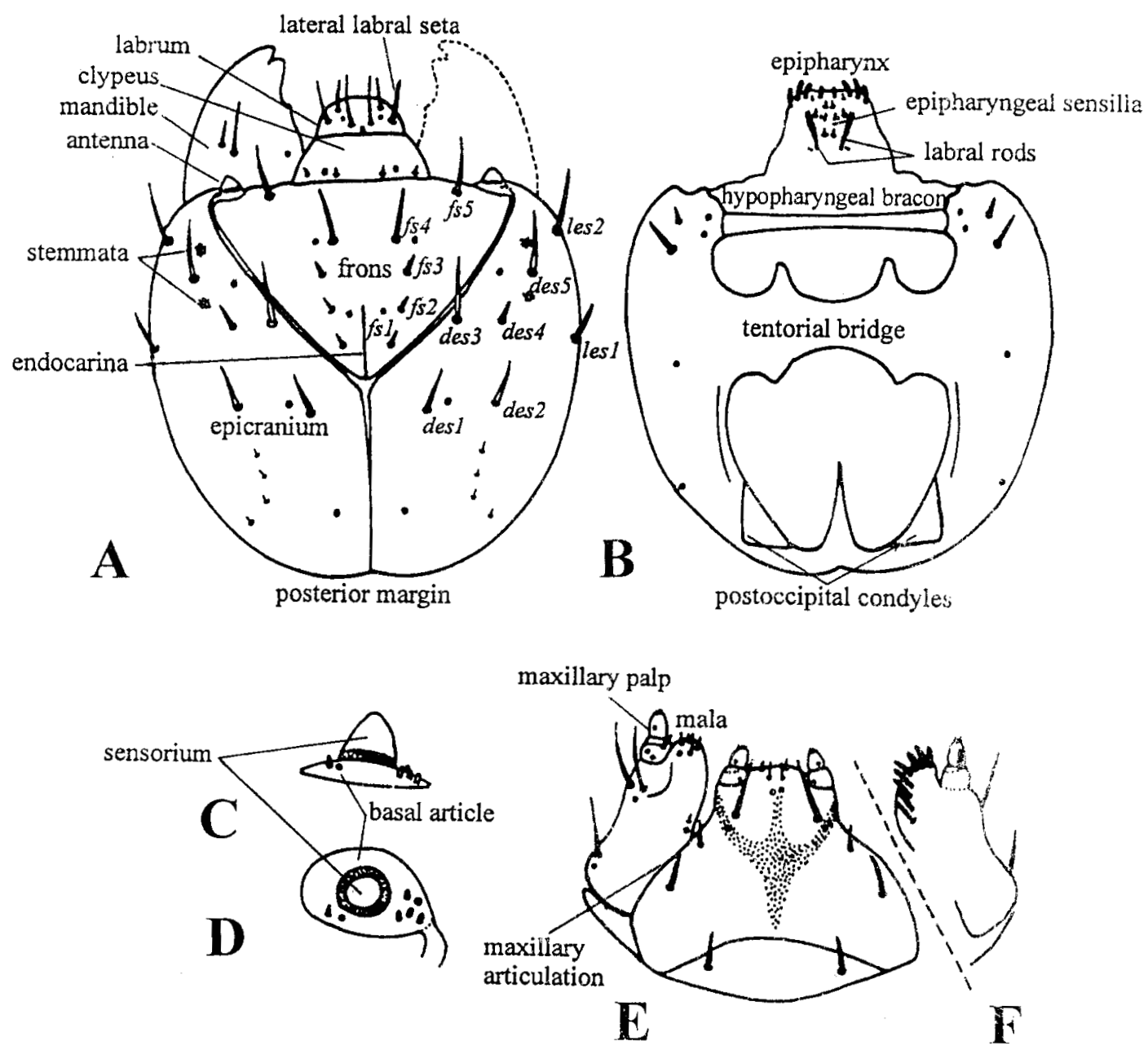

Fig. 1: A generalized weevil larva: (A) head, dorsal; (B) head, ventral; (C) antenna, lateral; (D) antenna, apical; (E) maxilla and labium, ventral; (F) maxilla, dorsal. 


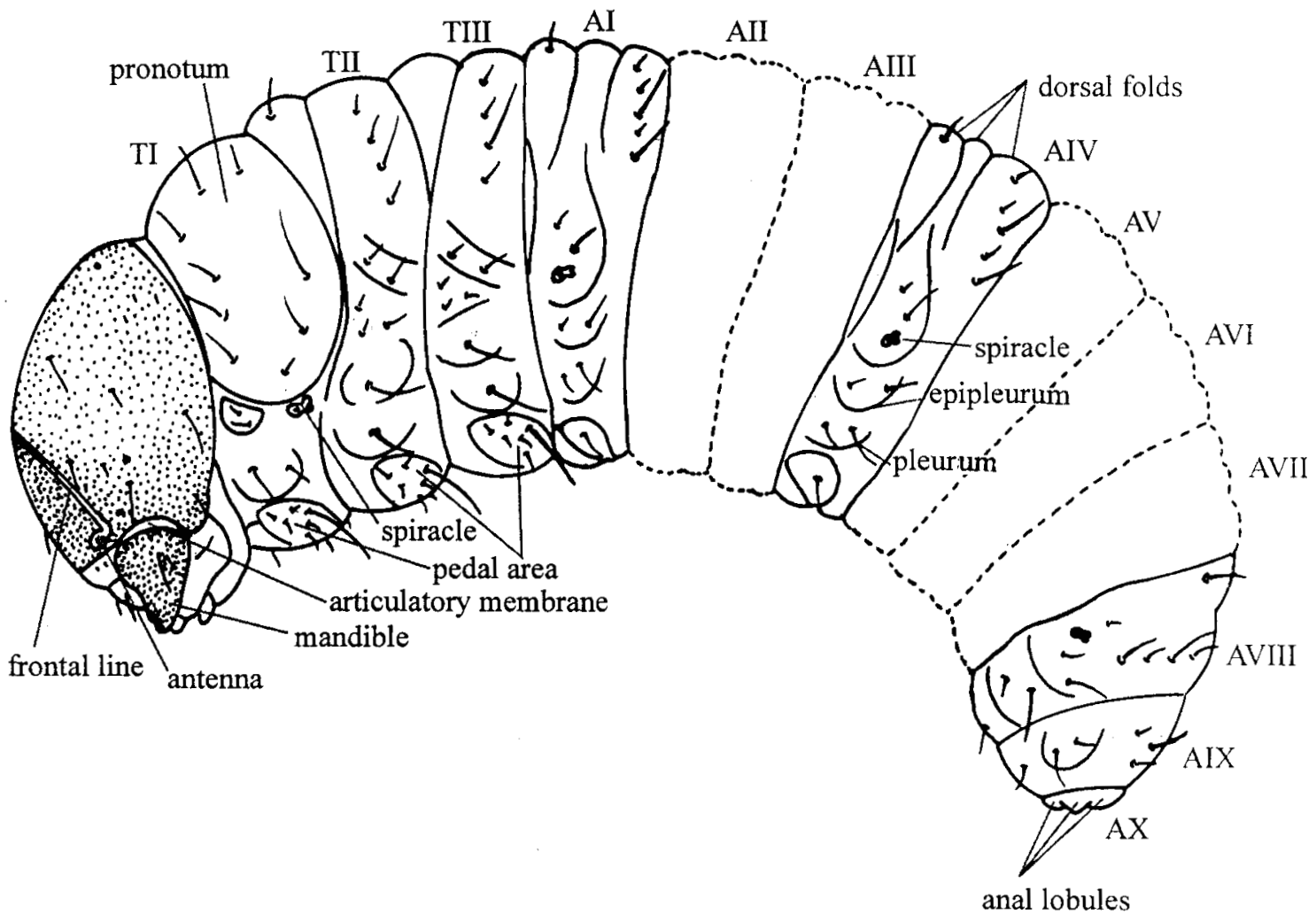

Fig. 2: A generalized weevil larva, lateral aspect.

Una larva de gorgojo generalizada, aspecto lateral.

folds or plicae; legs absent or vestigial; head hypognathous, with reduced antennae (usually one-segmented, rarely two-segmented, plus the sensorium); hypopharyngeal bracon present (except in some leaf-miners and platypodines); maxilla with a single apical lobe or mala; abdominal tergum IX without urogonphi; spiracles annular, with or without airtubes.

Comparative notes: larvae of some Chrysomeloidea [Cerambycidae, Megalopodidae, and Chrysomelidae (including Bruchinae)] can be confused with weevil larvae, but all of the former differ in lacking a hypopharyngeal bracon and most of them differ in having legs. Legless larvae of Cerambycidae, as well as those of Buprestidae, can be separated from weevil larvae by their straight body and enlarged prothorax. Larvae of Scarabaeoidea can be distinguished from weevil larvae on the basis of their strongly curved (Ushaped) body, well-developed legs, and cribiform and reniform spiracles.

\section{MATERIAL AND METHODS}

\section{Classification}

Current classifications of weevils vary greatly in the number of families and subfamilies recognized, but the differences are mostly in rank and the concepts or genera included in each higher taxon generally agree (e.g., Thompson 1992, Zimmerman 1993, 1994a, 1994b, Kuschel 1995, Lawrence \& Newton 1995). In the present paper the weevils are classified in seven families (Nemonychidae, Anthribidae, Belidae, Attelabidae, Caridae, Brentidae, and Curculionidae), according to recent phylogenetic studies (Kuschel 1995, Marvaldi et al. 2002). In the recent world catalogue of Curculionoidea (Alonso-Zarazaga \& Lyal 1999), the genera are arranged into a larger number of families (22), mainly following Thompson (1992), and Zimmerman 
(1993, 1994a, 1994b). As a consequence, several subfamilies in the present paper (i.e., Oxycoryninae, Rhynchitinae, Apioninae, Dryophthorinae, Erirhininae, and Platypodinae) are considered to have family rank in the catalogue. Remaining subfamilies in Curculionidae are in agreement with the catalogue, with some minor differences: in the present work the concept of Entiminae excludes Thecesterninae (Marvaldi 1997), the concept of "Curculioninae" excludes Eugnominae (Marvaldi, unpublished data), and also the Aterpinae, Rhythyrrininae and Gonipterinae are kept as subfamilies instead of tribes of Cyclominae. A natural classification of the family Curculionidae into subfamilies still is incipient and some concepts of the subfamilies used herein, although practical for the purpose of identification in the key, may correspond to para- or polyphyletic taxa.

\section{Characters and terminology}

The key is based on external morphology. Information on larval habits, such as host tissues most frequently consumed, also is provided. Observation of most larval structures requires the larvae to be dissected and slide-mounted for examination under a compound microscope. Techniques to study larval material are provided in the references cited below. Generally it is necessary to separate the head, mouth-parts and cuticle, to clear them in $\mathrm{KOH}$, transfer them to ethanol, and then place the pieces in glycerine or make permanent slides in euparal or a similar media. The morphology of a generalized weevil larva and terms used in the key are indicated in Fig. 1 and 2. The larval characters were gathered mainly from Costa et al. (1988), Anderson (1991a, 1991b, 1991c, 1991d), May (1993, 1994), Marvaldi (1997, 1998a, 1998b, 1998c, 1999), Marvaldi \& Morrone (1998), Lanteri et al. (2002), and many couplets are modified from May (1993). Terminology employed also follows those sources, as in Marvaldi (1999).

\section{RESULTS AND DISCUSSION}

The following key should be considered preliminary, since it could be tested with South American representatives for some but not for all of the subfamilies. However, it was developed with the aim to be useful for as many regions as possible, and given the conservative nature of most larval characters, I am confident that most couplets are predictive to South America.
Key to weevil larvae

1. Hypopharyngeal bracon (head, ventral) with median sclerome (as in Fig. 3A and $3 \mathrm{~B})$; maxilla with articulatory lobe welldeveloped (as in Fig. 3C) 2

1'. Hypopharyngeal bracon without median sclerome (as in Fig. 1B); maxilla without articulatory lobe (as in Fig. 1E) ................ 3

2. Frons produced forward forming "pseudoclypeus", fronto-clypeal suture indistinct; frontal area with five pairs of setae (not counting clypeal setae) (as in Fig. 1A); mandible with diagonal ridge in molar area (as in Fig. 3D). Tentorial bridge entire (as in Fig. 1B and 3A). In male cones of conifers (e.g., Araucaria) or male flowers of Nothofagaceae ........ NEMONYCHIDAE: Rhinorhynchinae

2'. Frons not produced forward, frontoclypeal suture distinct (as in Fig. 1A) or indistinct; frontal area usually with more than five pairs of setae; mandible without diagonal ridge in molar area. Tentorial bridge divided laterally (as in Fig. 3B). Fungus feeders, usually in dead wood or decaying plant tissues ..... ANTHRIBIDAE: Anthribinae

3. Head deeply invaginated into thorax (as in Fig. 3G), attached by heavy musculature, not extrusible; antennae usually with retractable basal membrane (as in Fig. 3E and $3 \mathrm{~F}$ ); labrum with sclerotized rods lateral in position ("labral tormae") [sometimes indistinct].....BELIDAE ........ 4

3'. Head exposed (as in Fig. 2), if partially invaginated, then extrusible; antennae without retractable basal membrane; labral rods submedian in position (as in Fig. 1B, $4 \mathrm{I}$ and $4 \mathrm{~J}$ ) ................................................. 5

4. Antenna (with retractable basal membrane) two-segmented, with apical (cylindrical) segment accompanying the (conical) sensorium (as in Fig. 3E). Posterior margin of pronotum slopped back and thickened (as in Fig. 3G). Borers in dead or decaying branches or twigs ........ BELIDAE: Belinae

4'. Antenna (with or without retractable basal membrane) one-segmented, lacking apical (cylindrical) segment accompanying the (conical) sensorium 
hypopharyngeal bracon and sclerome

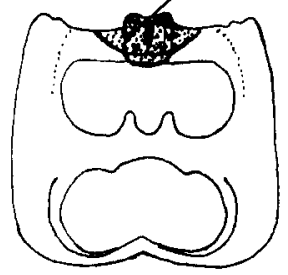

A
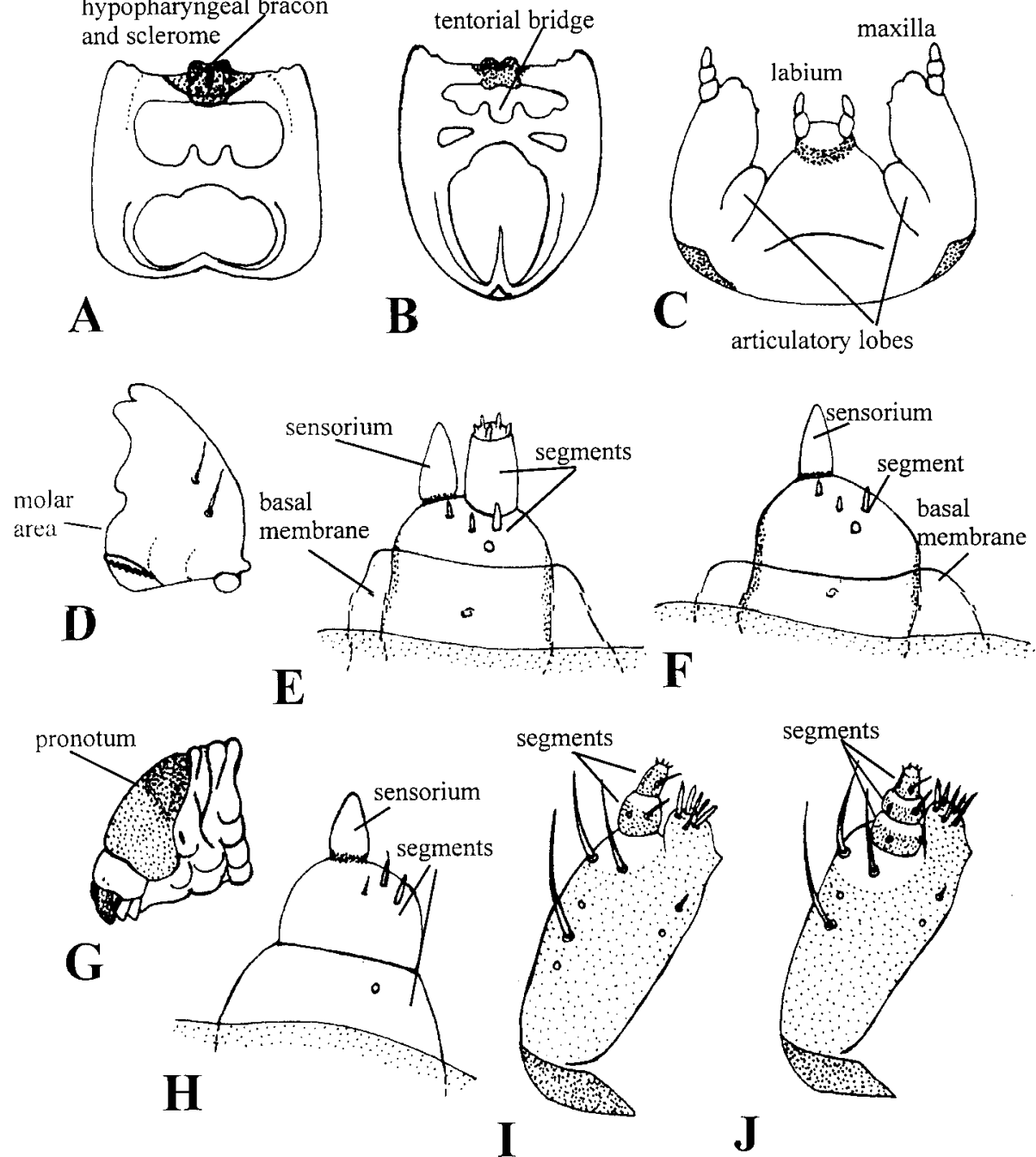

Fig. 3: (A) Head, ventral (Nemonychidae); (B) head, ventral (Anthribidae); (C) maxillae and labium, ventral (Nemonychidae); (D) mandible (Nemonychidae); (E) antenna (Belidae: Belinae); (F) antenna (Belidae: Oxycoryninae); (G) head and thorax (Belidae: Belinae); (H) antenna (Attelabidae); (I) maxilla, ventral (Attelabidae: Attelabinae); (J) maxilla, ventral (Attelabidae: Rhynchitinae).

(A) Cabeza, ventral (Nemonychidae); (B) cabeza, ventral (Anthribidae); (C) maxila y labio, ventral (Nemonychidae); (D) mandíbula (Nemonychidae); (E) antena (Belidae: Belinae); (F) antena (Belidae: Oxycoryninae); (G) cabeza y tórax (Belidae: Belinae); (H) antena (Attelabidae); (I) maxila, ventral (Attelabidae: Attelabinae); (J) maxila, ventral (Attelabidae: Rhynchitinae).

(as in Fig. 3F). Posterior margin of pronotum simple (as in Fig. 2). Borers in reproductive parts of parasitic dicots or in cones of conifers (Araucaria)

BELIDAE: Oxycoryninae

5. Posterior margin of head (when separated from thorax by dissection) with hyaline posterior extension. Antenna twosegmented (as in Fig. 3H).

ATTELABIDAE
5'. Posterior margin of head without posterior extension (as in Fig. 1A). Antenna onesegmented (as in Fig. 1A and 1C) 7

6. Maxillary palp two-segmented (as in Fig. 3I). Inside leaf-rolls made by adult female ....... ATTELABIDAE: Attelabinae

6'. Maxillary palp three-segmented (as in Fig. 3J). In decaying flower buds or fruits ....... ATTELABIDAE: Rhynchitinae 
7. Head with more than three stemmata (larval ocelli). Maxillary palp with seta on apical segment (as in Fig. 3I). [Segmented legs present]. In female cones of Cupressaceae CARIDAE: Carinae

7'. Head with two or fewer stemmata (as in Fig. 1A). Maxillary palp without seta on apical segment (as in Fig. 1E). [Legs usually absent or vestigial] 8

8. Postoccipital condyles absent. Frontal lines complete, extending to articulating membrane of mandible (as in Fig. 4A). Legs present or absent. Abdominal segments IIVII with two dorsal folds (except three to four in Brentinae)......BRENTIDAE 9

8'. Postoccipital condyles usually present (as in Fig. 1B). Frontal lines incomplete, not extending to articulating membrane of mandible (as in Fig. 2 and 4B). Legs absent (as in Fig. 2). Abdominal segments II-VII with three to four dorsal folds (as in Fig. 2) CURCULIONIDAE. 10

9. Spiracle of abdominal segment VIII present (as in Fig. 2, with one thoracic and eight abdominal spiracles); abdominal segments II-VII with three to four dorsal folds. Head with five pairs of frontal setae. In dead or decaying wood, usually under bark with fungi, Taphroderini are predaceous and act as kleptoparasites of some Scolytinae and Platypodinae...... BRENTIDAE: Brentinae

[Cyladinae, with Cylas formicarius feeding in sweet potato tubers, is introduced into South America and now present in Venezuela, also would key out here, except for the presence of indistinct dorsal folds. The thoracic pedal areas have two concentric sclerites (vestigial leg segments)].

9'. Spiracle of abdominal segment VIII absent (with one thoracic and seven abdominal spiracles); abdominal segments II-VII with two dorsal folds. Head with two to four pairs of frontal setae. In living plant tissues, stems or roots (sometimes galls form), seeds, leaves BRENTIDAE: Apioninae

10. Epipharynx and/or maxillary mala usually with some branched or tufted setae. Abdomen expanded by subdivided pleural areas in several superimposed lobes ...... 11
10'. Epipharynx and maxilla with simple setae (as in Fig. 1B and 1E). Abdomen not expanded by subdivided pleural areas (as in Fig. 2) 12

11. Head (ventral) with hypopharyngeal bracon (as in Fig. 1B); with or without postoccipital condyles; clypeus welldeveloped (as in Fig. 1A). Many species develop in decaying tissues (stems, roots) of monocots, mainly grasses and palms, some in seeds or stored grains, and others in rotten wood ............ CURCULIONIDAE: Dryophthorinae

11'. Head (ventral) lacking hypopharyngeal bracon; lacking postoccipital condyles; clypeus often reduced to narrow transverse band. Wood borers feeding on ambrosia fungi that line their tunnels .... CURCULIONIDAE: Platypodinae

12. Head with epicranial seta 3 (des 3 ) placed on frontal line or on frons (as in Fig. 4G) 13

12'. Head with epicranial seta 3 (des3) placed on epicranium (as in Fig. 1A) 17

13. Head relatively small in relation to body, usually with salient postoccipital condyles; spiracles often modified for aquatic life (i.e., upstanding, placed on dorsum and plant-piercing, adapted to extract oxygen from aerenchyma tissue of host-plants). In stems, roots or leaves of aquatic or semiaquatic plants (mostly monocots and ferns) ...... CURCULIONIDAE: Erirhininae

13'. Head in proportion to body size, with postoccipital condyles rarely salient (as in Fig. 1B), spiracles generally not modified 14

14. Antennal sensorium cushion-like (as in Fig. 4C), elliptic in apical view (as in Fig. 4D); maxillary mala with four ventral setae (as in Fig. 4E). In soil, feeding on roots (adults eat leaves) ........ CURCULIONIDAE: Entiminae

14'. Antennal sensorium conical (as in Fig. 1C), circular in apical view (as in Fig. 1D); maxillary mala with five ventral setae (as in Fig. 4F) CURCULIONIDAE: "Cyclominae" 15

15. Lateral labral seta well-developed (as in Fig. 1A). Antenna (head, dorsal) 

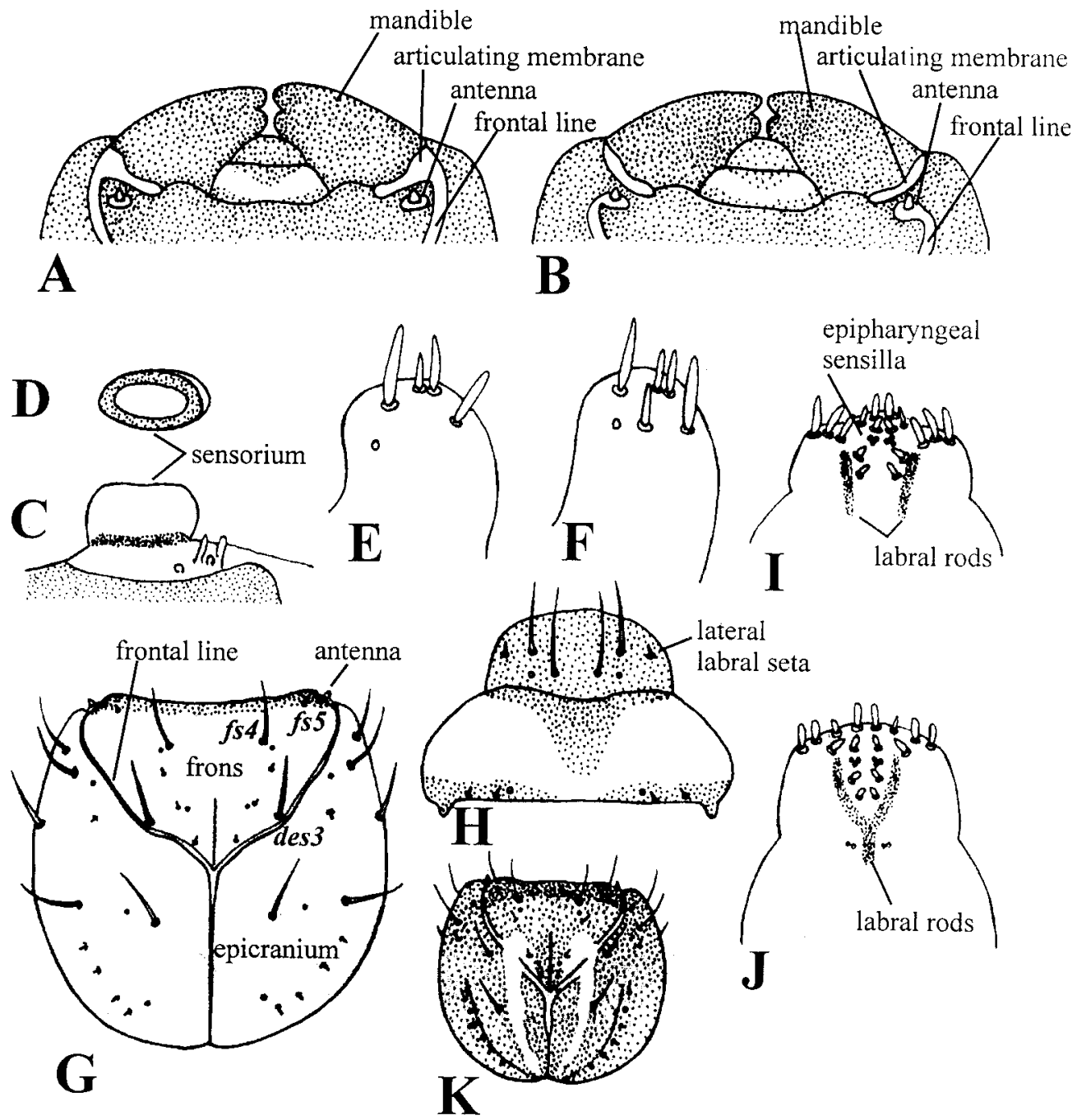

Fig. 4: (A) Apex of head (Brentidae); (B) apex of head (Curculionidae); (C and D) antenna (Curculionidae: Entiminae): (C) lateral, (D) apical; (E) maxillary mala, ventral (Curculionidae: Entiminae); (F) maxillary mala, ventral (Curculionidae: Aterpinae); $(G)$ head capsule, dorsal (Curculionidae: Aterpinae); (H) labrum and clypeus (Curculionidae: Rhythirrininae); (I) epipharynx (Curculionidae: Curculioninae); (J) epipharynx (Curculionidae: Cryptorhynchinae); (K) head capsule, dorsal (Curculionidae: Baridinae).

(A) Ápice de la cabeza (Brentidae); (B) ápice de la cabeza (Curculionidae); (C y D) antena (Curculionidae: Entiminae): (C) lateral, (D) apical; (E) mala maxilar, ventral (Curculionidae: Entiminae); (F) mala maxilar, ventral (Curculionidae: Aterpinae); (G) cápsula cefálica, dorsal (Curculionidae: Aterpinae); (H) labro y clípeo (Curculionidae: Rhythirrininae); (I) epifaringe (Curculionidae: Curculioninae); (J) epifaringe (Curculionidae: Cryptorhynchinae); (K) cápsula cefálica, dorsal (Curculionidae: Baridinae).

partially hidden by frontal projection (as in Fig. 4G). Borers in roots or green wood...... CURCULIONIDAE: Aterpinae

15'. Lateral labral seta vestigial (or much shorter than others) (as in Fig. 4H) or absent. Antenna exposed (as in Fig. 1A) .. 16
16. Pronotum cleft medially and produced hoodlike over head. Introduced (in Argentina, Brasil, Uruguay and Chile) from Australian region and ectophytic on leaves of Eucalyptus trees CURCULIONIDAE: Gonipterinae

16'. Pronotum entire, not produced over head (as in Fig. 2). Native species. Larvae ecto- and 
endophytic on diverse herbaceous plants and plant parts CURCULIONIDAE: Rhythirrininae

17. Postoccipital condyles absent or vestigial; spiracle of abdominal segment VIII lateral (as in Fig. 2) 18

17'. Postoccipital condyles present (as in Fig. 1B); spiracle of abdominal segment VIII lateral or dorsal 20

18. Head usually invaginated and without endocarina. Prothorax expanded and pedal lobes salient. Borers in dead or dying branches CURCULIONIDAE: Mesoptiliinae (= Magdalidinae)

18'. Head exposed and usually with endocarina present (as in Fig. 1A). Prothorax and pedal areas with normal aspect (as in Fig. 2) 19

19. Head with four pairs of frontal setae (except Araucariini, with five). Abdominal segment IX with only two pairs of dorsal setae. Borers in dead or dying wood or woody tissues. Members of the cossonine tribe Araucariini, associated with Araucariaceae trees, are similar to scolytines in that both adult and larvae tunnel under bark, often in branches also occupied by scolytines ... CURCULIONIDAE: Cossoninae

19'. Head with five pairs of frontal setae (as in Fig. 1A). Abdominal segment IX with three to four pairs of dorsal setae (as in Fig. 2). Many species in galleries under bark (bark beetles) that form a feather pattern, others bore directly in the wood and live on ambrosia fungi that they plant in their galleries CURCULIONIDAE: Scolytinae

20. Frontal seta 5 ( $f s 5$ in Fig. 1A) longer than frontal seta 4 ( $f s 4)$; head with maculae; body pigmented, with ambulatory ampullae; some dorsal setae of body short and expanded at apex. Ectophytic on leaves CURCULIONIDAE: Hyperinae

20'. Frontal setae 5 and 4 ( $f s 5$ and $f s \quad 4$ ) subequal in length (as in Fig. 1A) or $f s 5$ shorter than $f_{s} 4$ (as in Fig. 4G); head not maculate; body whitish, without ambulatory ampullae; dorsal setae tapering
21. Abdominal spiracle VIII placed on dorsum. (Frontal seta 5 well-developed, similar to frontal seta 4 (as in Fig. 1A) ..................... 22

21'. Abdominal spiracle VIII placed laterally (as in Fig. 2), if dorsal, then frontal seta 5 vestigial (as in Fig. 4G) or much shorter than frontal seta 4 23

22. Anal segment with four lobules (as in Fig. 2); labral rods separated (as in Fig. 1B and 4I) or convergent. Endophytic in a variety of niches, usually in living or decaying tissues of woody plants, some (e.g., Cholini) borers in stems of monocots, others (e.g., Conotrachelini) inside fruits and nuts of dicots ...... CURCULIONIDAE: Molytinae

22'. Anal segment with six to eight lobules; labral rods convergent. In various living or decaying plant tissues (adults pollen feeders) CURCULIONIDAE: Eugnominae

23. Labral rods convergent, usually united at base.

23'. Labral rods separated, usually subparallel (as in Fig. 1B and 4I) 25

24. Head exposed (as in Fig. 2). Labral rods usually united by basal stem (as in Fig. $4 \mathrm{~J})$. Endophytic in living to decayed plant tissues CURCULIONIDAE: Cryptorhynchinae

24'. Head invaginated into thorax. Labral rods without basal stem. Borers in living or dead wood or stems CURCULIONIDAE: Conoderinae (= Zygopinae)

25. Head capsule (dorsal) with a pallid Vshaped band (as in Fig. 4K), sometimes also with a dark line or ridge on each epicranial halve (as in Fig. 4K). Borers in flowers, stems and roots of herbaceous plants, in palm fruits, grasses and other monocots .. CURCULIONIDAE: Baridinae

25'. Head without pallid V-shaped band and dark epicranial ridge 26

26. Antennal sensorium hemispherical. Endocarina absent. In petioles, base of stems or root collar of herbaceous plants CURCULIONIDAE: Ceutorhynchinae 
26'. Antennal sensorium conical (as in Fig. 1A and $1 \mathrm{C}$ ). Endocarina usually present (as in Fig. 1A) 27

27. Cephalic setae well-developed (as in Fig. 1A). Head subcircular (as in Fig. 1A). Mostly root feeders; some lixine larvae develop in flower buds or stems . CURCULIONIDAE: Lixinae, Thecesterninae

27'. Cephalic setae reduced in size and number: usually only frontal seta $4(f s 4)$, dorsoepicraneal 5 (des5) and lateral 1 (les 1 ) well-developed. Head sometimes emarginate posteriorly. Endophytic in a variety of niches, in living plant tissues: stem-borers, leaf-miners, in flower buds, fruits or seeds. Mostly associated with dicots, but some derelomines develop in reproductive structures of gymnosperms and palms, and some erodiscines are associated with aquatic monocots Curculioninae sensu lato

[The curculionine tribes are difficult to separate using larval characters, but some are distinct: Anthonomini are distinguished by having four epipharyngeal sensilla (instead of six as in Fig. 1B and 4I) and by lacking frontal seta 2. The introduced (in Brasil) Gymnetrini are quite divergent in having abdominal segments with only two dorsal folds and expanded pedal lobes.]

\section{ACKNOWLEDGEMENTS}

I am grateful to Analía Lanteri for helpful comments on an earlier version, to Charles O'Brien and Guillermo Wibmer for reviewing the manuscript, and to Sergio Roig-Juñent for assistance with the figures. I also acknowledge the support from CONICET (Consejo Nacional de Investigaciones Científicas y Técnicas, Argentina).

\section{LITERATURE CITED}

ALONSO-ZARAZAGA M \& CHC LYAL (1999) A world catalogue of families and genera of Curculionoidea (Insecta: Coleoptera) (Excepting Scolytidae and Platypodidae). Entomopraxis, Barcelona, Spain. $315 \mathrm{pp}$.

ANDERSON DM (1991a) Nemonychidae (Curculionoidea). In: Stehr FW (ed) Immature insects, Volume 2: 585586. Kendall/Hunt, Dubugue, Iowa, USA

ANDERSON DM (1991b) Anthribidae (Curculionoidea). In: Stehr FW (ed) Immature insects, Volume 2: 586-589. Kendall/Hunt, Dubugue, Iowa, USA.
ANDERSON DM (1991c) Brentidae (Curculionoidea). In: Stehr FW (ed) Immature insects, Volume 2: 592593. Kendall/Hunt, Dubugue, Iowa, USA.

ANDERSON DM (1991d) Curculionidae (broad sense) (Curculionoidea). In: Stehr FW (ed) Immature insects, Volume 2: 594-612. Kendall/Hunt, Dubugue, Iowa, USA.

BURKE HR \& DM ANDERSON (1976) Systematics of larvae and pupae of American Curculionoidea: status report, historical review and bibliography. Southwestern Entomologist 1: 56-73.

COSTA C, SA VANIN \& SA CASARI-CHEN (1988) Larvas de Coleoptera do Brasil. Museu de Zoologia, Universidad de São Paulo, São Paulo, Brasil. 261 pp. +146 plates.

KUSCHEL G (1995) A phylogenetic classification of Curculionoidea to families and subfamilies. Memoirs of the Entomological Society of Washington 14: 5-33.

LANTERI AA, MS LOIÁCONO \& AE MARVALDI (2002) Anthonomus (Coleoptera: Curculionidae) asociados con el algodonero en Argentina. Revista de la Sociedad Entomológica Argentina 61: 24-26.

LAWRENCE JF (1991) Order Coleoptera. In: Stehr FW (ed) Immature insects, Volume 2: 144-184. Kendall/Hunt, Dubugue, Iowa, USA.

LAWRENCE JF \& AF NEWTON (1995) Families and subfamilies of Coleoptera (with selected genera, notes, references and data on family-group names). In: Pakaluk J \& S Slipinsky (eds) Biology, phylogeny, and classification of Coleoptera: 779-1006. Museum I Instytut Zoologii PAN, Warsaw, Poland.

MARVALDI AE (1997) Higher level phylogeny of Curculionidae (Coleoptera: Curculionoidea) based mainly on larval characters, with special reference to broad-nosed weevils. Cladistics 13: 285-312.

MARVALDI AE (1998a) Larvae of South American Rhytirrhininae (Coleoptera: Curculionidae). The Coleopterists Bulletin 52: 71-89.

MARVALDI AE (1998b) Larvae of Entiminae (Coleoptera: Curculionidae): tribal diagnoses and phylogenetic key, with a proposal about natural groups within Entimini. Entomologica Scandinavica 29: 89-98.

MARVALDI AE (1998c) Larvae of South American Entimini (Coleoptera: Curculionidae), and phylogenetic implications of certain characters. Revista Chilena de Entomología (Chile) 25: 21-44.

MARVALDI AE (1999) Morfología larval en Curculionidae (Insecta: Coleoptera). Acta Zoológica Lilloana 45: 7-24.

MARVALDI AE \& JJ MORRONE (1998) Immature stages of Rhyparonotus altarensis (Olliff) (Coleoptera: Curculionidae: Molytinae), with comments on larval characters in Anchonini and Molytinae. Journal of the New York Entomological Society 106: 95-104.

MARVALDI AE, AS SEQUEIRA, CW O'BRIEN \& BD FARRELL (2002) Molecular and morphological phylogenetics of weevils (Coleoptera, Curculionoidea): do niche shifts accompany diversification? Systematic Biology 51: 761-785.

MAY BM (1993) Larvae of Curculionoidea (Insecta: Coleoptera): a systematic overview. Fauna of New Zealand 28: 1-221.

MAY BM (1994) An introduction to the immature stages of Australian Curculionoidea. In: Zimmerman's Australian weevils, Volume II: 365-755. CSIRO, Melbourne, Australia.

ROSADO-NETO GH (1980) Description of larva and pupa of Heilipodus erythropus (Klug, 1829) (Coleoptera, 
Curculionidae). Revista Brasileira de Entomologia 24: 111-115.

THOMPSON RT (1992) Observations on the morphology and classification of weevils (Coleoptera, Curculionoidea) with a key to major groups. Journal of Natural History 26: 835-891.

WIBMER GJ \& CW O'BRIEN (1986) Annotated checklist of the weevils (Curculionidae sensu lato) of South America (Coleoptera: Curculionoidea). Memoirs of the American Entomological Institute 39: 1-563.

Associate Editor: Juan Carlos Torres-Mura

Received January 14, 2003; accepted July 4, 2003
ZIMMERMAN EC (1993) Australian weevils. Volume III. Nanophyidae, Rhynchophoridae, Erirhinidae, Curculionidae: Amycterinae, literature consulted. CSIRO, Melbourn, Australia. $x+854$ pp.

ZIMMERMAN EC (1994a) Australian weevils. Volume I. Orthoceri: Anthribidae to Attelabidae. CSIRO, Melbourne, Australia. xxxii +741 pp.

ZIMMERMAN EC (1994b) Australian weevils. Volume II. Brentidae, Eurhynchidae, Apionidae and a chapter on immature stages by Brenda May. CSIRO, Melbourne, Australia. $x+755$ pp. 